\title{
ANALISIS KINERJA MANAJEMEN PERSEDIAAN PRODUK UD. SINAR JAYA KARANGASEM
}

\author{
I Putu Adi Sanjaya ${ }^{1}$ \\ Ni Ketut Purnawati ${ }^{2}$ \\ ${ }^{1,2}$ Fakultas Ekonomi dan Bisnis Universitas Udayana (Unud), Bali, Indonesia \\ email: adisanjaya818@gmail.com
}

\begin{abstract}
ABSTRAK
Persediaan sangat berperan penting dalam kegiatan operasional perusahaan, maka perlu dilakukan manajemen persediaan agar meminimalkan kerugian yang disebabkan oleh besarnya biaya-biaya persediaan. Penelitian ini dilakukan di UD. Sinar Jaya, bertujuan untuk mengetahui kinerja manajemen persediaan produk dan apakah kinerja tersebut sudah efisien atau belum. Data penelitian diperoleh melalui wawancara dan observasi. Teknik analisis data yang digunakan adalah teknik analisis deskriptif yang menjelaskan secara sistematis beberapa tahapan yang diawali dengan analisis $\mathrm{ABC}$, dilanjutkan dengan perhitungan $\mathrm{EOQ}$, perhitungan safety stock, perhitungan reorder point, perhitungan persediaan maksimal, perhitungan inventory turnover, dan diakhiri dengan membandingkan total biaya persediaan antara metode yang diterapkan perusahaan dengan metode EOQ. Hasil penelitian menunjukkan bahwa kinerja manajemen persediaan produk belum efisien. Hal ini ditunjukkan oleh total biaya persediaan yang dikeluarkan dengan menggunakan metode perusahaan tahun 2019 sebesar Rp 43.058.137. Sistem manajemen persediaan produk yang seharusnya dilakukan adalah mengklasifikasikan produk dengan analisis $\mathrm{ABC}$, lalu menentukan EOQ sebesar 1.208 unit, menentukan safety stock sebesar 518 unit, dan menentukan reorder point sebesar 1.099 unit pada masing-masing unit klasifikasi A, sehingga total biaya persediaan yang dikeluarkan hanya sebesar $\mathrm{Rp} 32.716 .517$ atau $24,02 \%$ lebih rendah dari penerapan metode perusahaan yang sesungguhnya.
\end{abstract}

Kata kunci: analisis ABC, EOQ, biaya-biaya persediaan

\begin{abstract}
Inventory plays an important role in the company's operational activities, it is necessary to do inventory management in order to minimize losses caused by the large inventory costs. This research is conducted at UD. Sinar Jaya, aims to determine the performance of product inventory management and whether it's efficient or not. Research data are obtained through interviews and observations. Descriptive analysis technique is used, which describes systematically several stages starting with $A B C$ analysis, EOQ calculation, safety stock calculation, re-order point calculation, maximum inventory calculation, inventory turnover calculation, and comparing the total inventory cost between the method applied by the company with the EOQ method. Results show that product inventory management performance is not efficient. This is indicated by the total cost of inventory incurred using the company method in 2019 amounting to IDR 43,058,137. The product inventory management system that should be carried out is to classify products with ABC analysis, then determine EOQ of 1,208 units, determine safety stock of 518 units, and determine the reorder point of 1,099 units for each classification at unit A, so that the total cost of inventory incurred is only IDR $32,716,517$ or $24.02 \%$ lower than the actual application of company methods.
\end{abstract}

Keywords: $A B C$ analysis, EOQ, inventory costs 


\section{PENDAHULUAN}

Persediaan memiliki peran penting dalam kegiatan operasional perusahaan. Heizer \& Render (2015:553) menyatakan bahwa manajemen persediaan berperan untuk menentukan keseimbangan antara investasi persediaan dan pelayanan pelanggan. Seimbangnya investasi persediaan dan pelayanan pelanggan dapat menentukan keunggulan kompetitif jangka panjang perusahaan (Abdul, 2018). Peran penting lain dari manajemen persediaan yaitu untuk mengantisipasi berbagai kemungkinan yang bisa mengancam kegiatan operasional perusahaan (Najoan et al., 2019). Di samping itu, manajemen persediaan diperlukan perusahaan untuk mengambil keputusan dengan tepat agar ketersediaan produk menjadi optimal (Radasanu, 2016).

Perusahaan dapat mengoptimalkan peranan manajemen persediaan dengan mempertimbangkan biaya-biaya persediaan, diantaranya biaya penyimpanan, biaya pemesanan, biaya penyiapan, dan biaya kekurangan bahan (Handoko, 2019:336). Biaya-biaya tersebut tentunya dapat memengaruhi kinerja perusahaan dalam menjalankan manajemen persediaan. Jika dikelola dengan baik, biaya yang dikeluarkan menjadi ekonomis sehingga menjamin kelancaran operasional perusahaan. Sebaliknya jika tidak dikelola dengan baik, akan menimbulkan tingginya biaya yang dikeluarkan sehingga dapat mengganggu kegiatan operasional perusahaan (Macias, 2020).

Dalam menjalankan manajemen persediaan yang baik, Pujawan \& Mahendrawati (2010:119) menyatakan terdapat jenis persediaan berdasarkan sifat ketergantungan yang harus dikelola. Persediaan tersebut diklasifikasikan menjadi persediaan independen dan persediaan dependen. Persediaan independen adalah persediaan yang tidak tergantung pada kebutuhan unit lain, sedangkan persediaan dependen adalah persediaan yang tergantung pada kebutuhan unit lain. Untuk mengelola persediaan independen, perusahaan harus mengatur satu persatu komponen persediaannya dan jika memang terdapat komponen atau produk yang banyak maka perusahaan perlu membuat sistem. Salah satu sistem yang bisa dijadikan opsi yaitu analisis $\mathrm{ABC}$. Analisis $\mathrm{ABC}$ membagi persediaan produk ke dalam tiga kelompok berdasarkan pada volume tahunan dalam jumlah uang (Heizer \& Render, 2015:555).

Pengelolaan persediaan akan lebih baik lagi jika proses analisis dilanjutkan dengan menggunakan model kuantitas pesanan ekonomis (Economic Order Quantity atau EOQ) (Hafnika et al., 2016). Model EOQ adalah salah satu teknik pengendalian persediaan yang meminimalkan biaya total dari pemesanan dan penyimpanan (Heizer \& Render, 2015:561). Penerapan metode EOQ dapat menentukan frekuensi pemesanan dan jumlah pesanan produk yang paling ekonomis sesuai dengan kebutuhan perusahaan. Oleh karena itu, pemesanan ekonomis ini akan membantu perusahaan untuk memberikan tingkat layanan yang tinggi dengan biaya total yang minimal (Beck et al., 2015). Hal yang diperhatikan dalam penerapan metode EOQ yaitu titik pemesanan ulang, waktu tunggu, dan juga persediaan pengaman.

Titik pemesanan ulang (reorder point) adalah titik persediaan di mana perusahaan melakukan pemesanan kembali. Selanjutnya, waktu tunggu (lead time) adalah waktu menunggu mulai dari pemindahan, antrian, pemasangan, sampai 
dengan pengoperasian masing-masing komponen yang dihasilkan (Heizer \& Render, 2015:567). Terakhir, persediaan pengaman (safety stock) adalah jumlah simpanan persediaan di luar jumlah perkiraan permintaan. Ketiga hal tersebut diadakan perusahaan dengan tujuan untuk mengantisipasi kemungkinan terjadinya kekurangan produk (Listyorini, 2016).

Upaya untuk mengetahui kecepatan pergantian persediaan menjadi kas atau piutang dagang dapat dilakukan dengan menentukan tingkat perputaraan persediaan yang dapat diukur menggunakan alat ukur berupa tingkat perputaran persediaan atau inventory turnover. Tingkat perputaran persediaan ini melihat seberapa cepat produk atau barang mengalir relatif terhadap jumlah rata-rata yang tersimpan sebagai persediaan (Pujawan \& Mahendrawati, 2010:118). Semakin tinggi tingkat perputaran yang diperoleh, semakin baik perusahaan dalam melaksanakan operasionalnya, karena tidak ada persediaan yang menumpuk atau berlebihan (Syafitri, 2015).

Berdasarkan hasil penelitian sebelumnya terkait manajemen persediaan, diperoleh hasil bahwa setiap organisasi atau perusahaan penting untuk menerapkan pengendalian persediaan. Melalui penerapan manajemen persediaan, perusahaan mampu meningkatkan produktivitas kinerja (Soni et al., 2016). Penelitian serupa dilakukan oleh Barwa (2015), Asri et al. (2018) serta Micah et al. (2019). Gordon \& Gupte (2016) mengatakan bahwa penerapan manajemen persediaan merupakan modal perusahaan, yang jika tidak dikelola dengan baik dapat mengakibatkan pemborosan pengeluaran. Pernyataan tersebut didukung oleh penelitian yang dilakukan oleh Supit \& Jan (2015), Brahmandhika et al. (2016) serta Nilawati \& Giyanti (2016).

Hasil penelitian empiris selanjutnya terkait tahapan dalam pengendalian persediaan yang memperoleh hasil dapat memberikan manfaat untuk menunjang kinerja perusahaan. Seperti penelitian yang dilakukan oleh Mujiono \& Fauji (2017) yang terbukti secara efektif mengidentifikasi jenis persediaan menggunakan analisis ABC dengan memfokuskan pada klasifikasi A yang menghabiskan dana paling besar. Hasil penelitian serupa juga dinyatakan oleh Shu \& Indriyani (2015), Lestari (2015), dan Alfatih (2017). Dalam mencapai efisiensi biaya persediaan, tidak hanya dengan melakukan analisis $\mathrm{ABC}$, namun perusahaan juga perlu mempertimbangkan mengenai berapa jumlah pesanan yang ekonomis (Yanti \& Farida, 2016). Jumlah pesanan tersebut dapat diperoleh melalui metode EOQ yang terbukti lebih efisien dibandingkan dengan penerapan metode perusahaan yang diteliti. Hasil penelitian tersebut dikemukakan oleh Andira (2016), Nugraha et al., 2016), Juventia \& Hartanti (2016), Maryati (2016), Kumar et al. (2017), Sunhal \& Mangal (2017), Putra \& Purnawati (2018), Rambitan et al. (2018), Najoan et al. (2019), Chebet (2019) serta Putra \& Rahyuda (2019).

Usaha Dagang (UD) Sinar Jaya adalah usaha turun-temurun yang menjual bahan bangunan yang terletak di Kecamatan Rendang, Kabupaten Karangasem atau lebih tepatnya di Desa Menanga (arah ke Pura Besakih). Karakteristik produk yang dijual di UD. Sinar Jaya sangat beragam, diantaranya berbagai merek cat, berbagai merek semen, berbagai jenis besi, kaca, pipa, dan lainnya. Terdapat fluktuasi harga yang tinggi (ekstrem) antara produk perusahaan yang satu dengan produk yang lainnya serta beragamnya nilai produk yang dimiliki, sehingga perusahaan perlu 
memprioritaskan produk yang memiliki tingkat risiko kerusakan yang tinggi. Oleh karena itu, dari keseluruhan jenis produk yang berjumlah 275 unit, akan dilakukan analisis $\mathrm{ABC}$ terlebih dahulu dan dalam pembahasan selanjutnya akan dikelola produk dengan klasifikasi A.

Fenomena yang terjadi di UD. Sinar Jaya dalam mengontrol persediaan produknya yaitu jumlah pesanan yang fluktuatif, frekuensi pemesanan yang tidak konsisten, serta pemesanannya pun dilakukan hanya berdasarkan pengamatan pemilik usaha saja. Akibatnya sering kali terjadi kekurangan maupun kelebihan produk di gudang. Informasi tersebut diperoleh dari wawancara dengan karyawan bagian gudang UD. Sinar Jaya, yang dibuktikan dengan data pada awal bulan Januari tahun 2019 produk Semen Dynamix $40 \mathrm{~kg}$ mengalami stockout atau kekurangan persediaan. Hal ini dikarenakan UD. Sinar Jaya hanya melakukan pemesanan sebanyak 900 zak pada bulan Desember tahun 2018. Oleh karena itu, UD. Sinar Jaya melakukan peningkatan pemesanan dari bulan Januari hingga bulan Juli tahun 2019, yang mana jumlah pesanan menginjak di angka 2.415 zak. Hal ini dilakukan perusahaan dengan hanya mengandalkan pengamatan saja, sehingga pada akhir bulan Juli tahun 2019 perusahaan mengalami kelebihan persediaan hingga 1.508 zak yang menyebabkan banyak sekali produk Semen Dynamix $40 \mathrm{~kg}$ tersimpan di gudang. Akibatnya, biaya penyimpanan meningkat dan kesempatan produk-produk lainnya untuk menggunakan fasilitas gudang menjadi berkurang. Berdasarkan data tersebut, dapat dilihat bahwa dalam menangani persediaan, UD. Sinar Jaya rupanya belum menerapkan sistem manajemen persediaan yang seharusnya, sehingga terjadi inkonsistensi disetiap pemesanan produknya. Oleh karena itu, diperlukan sistem manajemen persediaan dengan metode EOQ untuk menentukan jumlah pesanan paling ekonomis sehingga dapat meminimalkan kerugian yang dialami perusahaan.

Handoko (2019: 335) menyampaikan terdapat tiga fungsi persediaan, diantaranya: 1) Decoupling. Decoupling adalah persediaan yang digunakan untuk mengantisipasi fluktuasi permintaan konsumen yang tidak dapat diramalkan; 2) Economic Lot Sizing. Economic lot sizing adalah penghematan yang dicerminkan oleh pengurangan biaya-biaya per unit yang diperoleh perusahaan karena pembelian pada lot tertentu; 3) Antisipation. Antisipation adalah persediaan yang diadakan untuk mengantisipasi perubahan musim dengan tujuan memperlancar proses produksi.

Menurut Handoko (2019:336) biaya persediaan terdiri dari empat macam, diantaranya: 1) Biaya penyimpanan. Biaya penyimpanan (holding cost atau carrying cost) terdiri atas biaya-biaya yang bervariasi secara langsung dengan kuantitas persediaan. Biaya-biaya yang termasuk sebagai biaya penyimpanan adalah: biaya-biaya fasilitas penyimpanan, biaya modal, biaya keusangan, biaya perhitungan fisik dan konsilasi laporan, biaya asuransi persediaan, biaya pajak persediaan, biaya pencurian, pengerusakan atau perampokan, biaya penanganan persediaan, dan sebagainya. Biaya penyimpanan persediaan biasanya berkisar antara 12 sampai 40 persen dari biaya atau harga barang; 2) Biaya pemesanan. Biaya pemesanan adalah biaya yang ditanggung perusahaan setiap kali melakukan pemesanan. Adapun biaya-biaya yang termasuk biaya pemesanan adalah: pemrosesan pesanan dan biaya ekspedisi, upah, biaya telephone, pengeluaran surat 
menyurat, biaya pengepakan dan penimbangan, biaya pemeriksaan (inspeksi) penerimaan, biaya pengiriman ke gudang, biaya hutang lancar dan sebagainya; 3) Biaya penyiapan. Biaya penyiapan adalah biaya yang dikeluarkan perusahaan dalam persiapan untuk memproduksi suatu produk. Komponen biaya penyiapan terdiri dari: biaya mesin-mesin menganggur, biaya persiapan tenaga kerja langsung, biaya scheduling, biaya ekspedisi dan sebagainya; 4) Biaya kehabisan atau kekurangan bahan. Biaya ini timbul bilamana persediaan tidak mencukupi adanya permintaan bahan. Biaya-biaya yang termasuk biaya kekurangan bahan adalah sebagai berikut: kehilangan penjualan, kehilangan pelanggan, biaya pemesanan khusus, biaya ekspedisi, selisih harga, terganggunya operasi, tambahan pengeluaran kegiatan manajerial dan sebagainya.

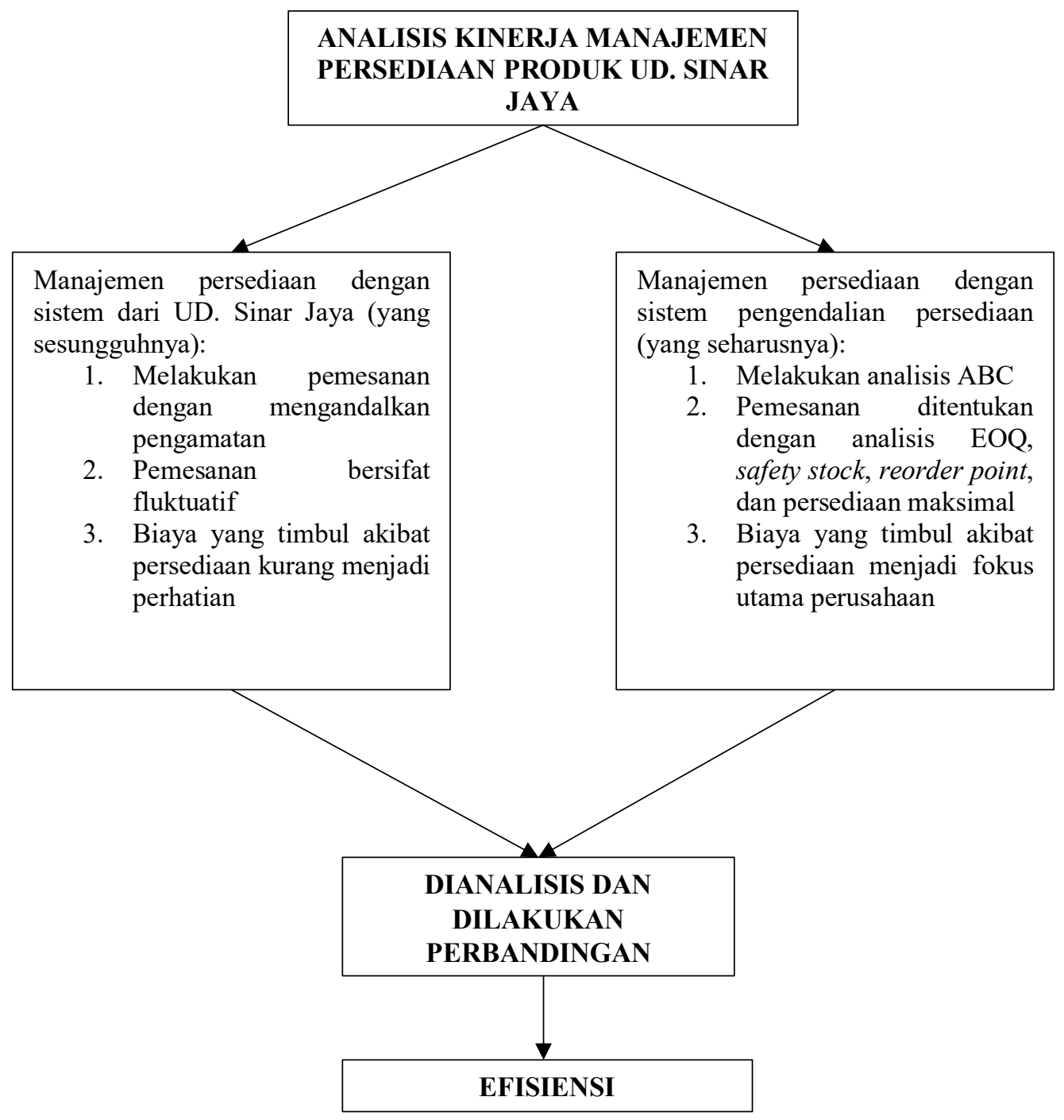

Gambar 1. Kerangka Konseptual Penelitian 


\section{METODE PENELITIAN}

Penelitian ini merupakan studi kasus secara menyeluruh mengenai persediaan pada UD. Sinar Jaya. Penelitian ini merupakan penelitian deskriptif dengan pendekatan kuantitatif untuk menganalisis permasalahan yang ada di UD. Sinar Jaya mengenai sistem persediaan serta melihat apakah kinerja manajemen persediaan perusahaan sudah efisien atau belum. Objek yang digunakan dalam penelitian ini adalah manajemen persediaan produk dagangan di UD. Sinar Jaya.

Lokasi penelitian yang dipilih yaitu UD. Sinar Jaya yang mana merupakan sebuah perusahaan yang bergerak di bidang usaha bahan bangunan yang terletak di Jalan Raya Besakih, Menanga, Rendang, Karangasem. UD. Sinar Jaya dinilai penting dalam melakukan manajemen persediaan karena karakteristik produk yang dijual sangat beragam dengan fluktuasi harga yang tinggi (ekstrem) serta beragamnya nilai produk yang dimiliki. Selanjutnya, pemesanan yang dilakukan UD. Sinar Jaya hanya berdasarkan pengamatan dengan jumlah pesanan yang berfluktuatif serta tidak menetapnya frekuensi pemesanan yang dilakukan. Akibatnya, sering kali terjadi stockout atau kekurangan maupun kelebihan persediaan. Oleh karena itu, manajemen persediaan di UD. Sinar Jaya sangat penting untuk dilakukan sehingga pengelolaannya menjadi lebih efisien. Untuk mengukur persediaan yang efisien, ditentukan dengan beberapa variabel yang digunakan dalam penelitian ini yaitu Economic Order Quantity (EOQ), Safety Stock (SS), Reorder Point (ROP), Persediaan Maksimal, Inventory Turnover (ITO) dan Total Inventory Cost (TC).

Economic Order Quantity merupakan perhitungan untuk menentukan jumlah pesanan produk paling ekonomis. Nilai dari EOQ ini dihitung menggunakan data tahun 2019, dengan rumus sebagai berikut:

$\mathrm{EOQ}=\sqrt{\frac{2 \mathrm{DS}}{\mathrm{H}}}$

Safety stock merupakan persediaan pengaman yang digunakan untuk mengantisipasi ketidakpastian permintaan sehingga dapat mencegah terjadinya stockout atau kekurangan persediaan. Nilai dari safety stock ini dihitung menggunakan data tahun 2019, dengan rumus sebagai berikut:

$\mathrm{SS}=\mathrm{Z} \times \mathrm{d} \times \mathrm{L}$

Reorder point merupakan titik pemesanan ulang yang menunjukkan tingkat persediaan dimana perusahaan UD. Sinar Jaya harus melakukan pemesanan produk agar aktivitas perusahaan dapat berjalan dengan lancar. Nilai dari reorder point ini dihitung menggunakan data tahun 2019, dengan rumus sebagai berikut:

$\mathrm{ROP}=\mathrm{d} \times \mathrm{L}$

Persediaan maksimal merupakan jumlah persediaan yang paling banyak dalam gudang. Nilai dari persediaan maksimal ini dihitung menggunakan data tahun 2019, dengan rumus sebagai berikut:

Persediaan Maksimal $=$ EOQ + SS

Inventory turnover merupakan sistem perputaran persediaan yang mengukur beberapa kali persediaan rata-rata terjual dalam satu periode. Nilai dari inventory turnover ini dihitung menggunakan data tahun 2019, dengan rumus sebagai berikut: 
ITO $=\frac{\text { Penjualan }}{\text { Rata-Rata Persediaan }}$

Total inventory cost merupakan total biaya persediaan yang dikeluarkan oleh perusahaan UD. Sinar Jaya. Nilai dari total inventory cost ini dihitung menggunakan data tahun 2019, dengan rumus sebagai berikut:

$\mathrm{TC}=\frac{\mathrm{Q}}{2} \mathrm{H}+\frac{\mathrm{D}}{\mathrm{Q}} \mathrm{S}$

Data kuantitatif yang digunakan dalam penelitian ini adalah adalah data yang diperlukan dalam penelitian, seperti biaya pemesanan, biaya penyimpanan, permintaan produk per unit per tahun, harga per unit produk, rata-rata permintaan per hari, service level, lead time, dan kuantitas setiap pemesanan produk yang dimiliki UD. Sinar Jaya dalam satu periode. Data kualitatif yang digunakan dalam penelitian ini adalah data mengenai gambaran umum perusahaan UD. Sinar Jaya.

Sumber primer yang digunakan adalah tentang kebijakan perusahaan dalam hal persediaan produk yang diperoleh dari hasil wawancara pemilik UD. Sinar Jaya. Sumber sekunder yang digunakan adalah data yang diperoleh dari laporan persediaan produk dagangan, biaya persediaan, jenis-jenis persediaan, serta data volume pemesanan produk di UD. Sinar Jaya. Metode pengumpulan data yang digunakan dalam penelitian ini adalah wawancara dan observasi. Teknik analisis data yang digunakan dalam penelitian ini adalah teknik analisis deskriptif.

\section{HASIL DAN PEMBAHASAN}

UD. Sinar Jaya merupakan perusahaan dagang yang menjual segala jenis bahan bangunan. UD. Sinar Jaya juga sudah memiliki gudang yang berlokasi tidak jauh dari tempat usahanya. Dengan berkembangnya perusahaan, jumlah tenaga kerjanya pun meningkat menjadi 16 orang dengan rincian 2 orang Karyawan Toko, 1 orang Karyawan Gudang, 4 orang Supir, 5 orang Buruh Angkut, dan 4 orang Buruh Cetak.

Produk perusahaan ini sudah berkembang dengan menjual beragam merek dan jenis bahan bangunan yang memiliki fluktuasi harga yang cukup tinggi (ekstrem) antara produk yang satu dengan produk yang lainnya. Produk-produk tersebut didatangkan melalui 6 pemasok bahan bangunan yang berada di Bali. UD. Sinar Jaya hanya memiliki satu induk perusahaan dengan jangkauan wilayah pemasaran tidak hanya di seputaran desa saja, namun sampai ke luar Kabupaten Karangasem.

Sebagai sebuah perusahaan dagang, UD. Sinar Jaya perlu menjaga kelancaran operasional perusahaannya dengan melaksanakan manajemen persediaan. Pada tahun 2019, UD. Sinar Jaya mengadakan persediaan mencapai 275 jenis produk dari beberapa pemasok yang tersebar di daerah Bali. Persediaan yang diadakan perusahaan meliputi beragam merek semen, berbagai jenis kaca, berbagai macam cat, kayu, dan masih banyak lagi (Lampiran 1). Metode yang digunakan perusahaan dalam menentukan kuantitas persediaan masih menggunakan pencatatan manual dibantu dengan pengamatan pemilik usaha dan pertimbangan karyawan gudang mengenai produk mana saja yang banyak diminati pelanggan. 
Tabel 1.

Total Biaya Persediaan Perusahaan Tahun 2019

Biaya Pemesanan

$\begin{array}{lcc}\text { Biaya Ekspedisi } & \mathrm{Rp} & 17.965 .000 \\ \text { Biaya Telepon } & \mathrm{Rp} & 4.950 .000 \\ \text { Biaya Bongkar Muat } & \mathrm{Rp} & 906.908\end{array}$

Biaya Penyimpanan

(20\% Nilai Persediaan) Rp $\quad$ 19.236.229

Total $\quad$ Rp 43.058 .137

Sumber: Data diolah, 2019

UD. Sinar Jaya melakukan pemesanan jumlah unit produk dengan mengamati sedikit banyaknya produk yang terjual pada bulan-bulan sebelumnya. Pada tahun 2019, perusahaan tercatat telah melakukan pemesanan sebanyak 58 kali dengan pengeluaran biaya pemesanan sebesar Rp 23.821.908. Perusahaan mengeluarkan biaya penyimpanan sebesar Rp 19.236.229 sehingga total biaya persediaan UD. Sinar Jaya pada tahun 2019 mencapai Rp 43.058.137. Analisis ABC dilakukan berdasarkan perhitungan persentase jumlah produk dan nilai investasi tahunan, lalu mengelompokkannya menjadi klasifikasi A, klasifikasi B, dan klasifikasi C.

Tabel 2.

Hasil Analisis ABC

\begin{tabular}{cccccc}
\hline \multirow{2}{*}{ Kelompok } & \multicolumn{2}{c}{ Jumlah Produk } & \multicolumn{3}{c}{ Nilai Investasi } \\
& $\begin{array}{c}\text { Jumlah } \\
\text { Unit }\end{array}$ & Persentase & Jumlah Investasi & Persentase \\
\hline A & 10 & $3,64 \%$ & Rp & 2.698 .812 .150 & $80,02 \%$ \\
B & 63 & $22,91 \%$ & Rp & 505.257 .779 & $14,98 \%$ \\
C & 202 & $73,45 \%$ & Rp & 168.498 .355 & $5,00 \%$ \\
Total & 275 & $100,00 \%$ & Rp 3.372 .568 .284 & $100,00 \%$ \\
\hline
\end{tabular}

Sumber: Data diolah, 2019

Persediaan bahan bangunan UD. Sinar Jaya sepanjang tahun 2019 mulai dari bulan Januari hingga Desember adalah Persediaan bahan bangunan yang masuk pada klasifikasi A adalah sebanyak 10 produk dengan persentase jumlah produk $3,64 \%$ serta jumlah investasi sebesar Rp 2.698.812.150 dengan persentase nilai investasi tahunan $80,02 \%$. Persediaan bahan bangunan yang masuk pada klasifikasi B adalah sebanyak 63 produk dengan persentase jumlah produk 22,91\% serta jumlah investasi sebesar Rp 505.257.779 dengan persentase nilai investasi tahunan 14,98\%. Persediaan bahan bangunan yang masuk pada klasifikasi $\mathrm{C}$ adalah sebanyak 202 produk dengan persentase jumlah produk 73,45\% serta jumlah investasi sebesar Rp 168.498.355 dengan persentase nilai investasi tahunan 5\%.

Persediaan bahan bangunan UD. Sinar Jaya pada klasifikasi A merupakan persediaan dengan nilai investasi tahunan paling besar sehingga dapat diklasifikasikan sebagai kelompok yang sangat kritis, sedangkan klasifikasi B 
adalah kelompok medium, dan klasifikasi $\mathrm{C}$ adalah kelompok kurang kritis. Penekanan yang harus dilakukan perusahaan yaitu dalam melakukan pengawasan dan kontrol persediaan fisik yang lebih ketat pada produk klasifikasi A, karena mempunyai nilai investasi yang tertinggi serta jika dilihat dari tingkat kerusakannya, produk-produk tersebut memiliki risiko kerusakan yang tinggi. Maka dari itu, dalam penelitian ini akan dilakukan manajemen persediaan hanya pada produk yang masuk dalam klasifikasi A saja.

Setelah melakukan analisis ABC, selanjutnya dilakukan perhitungan Economic Order Quantity (EOQ) yang bertujuan untuk menentukan kuantitas pesanan dengan biaya yang paling ekonomis. Perhitungan EOQ pada penelitian ini digunakan hanya pada produk yang masuk dalam klasifikasi A saja. Dengan menggunakan metode EOQ, UD. Sinar Jaya dapat mengurangi biaya persediaan sehingga akan menambah keuntungan perusahaan.

Rincian biaya persediaan yang digunakan dibagi menjadi dua, yakni biaya pemesanan dan biaya penyimpanan. Biaya pemesanan terdiri dari biaya ekspedisi, biaya telepon, dan biaya bongkar muat yang sudah diproporsikan menurut masingmasing pemasok. Biaya penyimpanan terdiri dari biaya modal, biaya kerusakan, dan biaya pemeliharaan. Besarnya biaya penyimpanan yaitu 20 persen dari nilai persediaan dimana persentase biaya modal yaitu 12 persen, biaya kerusakan 2 persen, dan biaya pemeliharaan 6 persen. Pembobotan biaya modal sebesar 12 persen diperoleh melalui perhitungan rata-rata tertimbang yang diketahui biaya laba ditahan (modal sendiri) sebesar 12 persen, biaya hutang 15 persen sebelum pajak, dan pajak penghasilan 25 persen. Adapun hasil perhitungannya adalah sebagai berikut:

Tabel 3.

Hasil Perhitungan Biaya Modal

\begin{tabular}{cccccc}
\hline Sumber Dana & & Jumlah & $\begin{array}{c}\text { Komposisi } \\
\text { Sumber Dana }\end{array}$ & $\begin{array}{c}\text { Biaya Modal } \\
\text { Setelah Pajak }\end{array}$ & $\begin{array}{c}\text { Rata-Rata } \\
\text { Tertimbang }\end{array}$ \\
\hline Modal Sendiri & $\mathrm{Rp}$ & 2.192 .705 .635 & $65 \%$ & $12 \%$ & $8 \%$ \\
Hutang & $\mathrm{Rp}$ & 1.180 .687 .649 & $35 \%$ & $11 \%$ & $4 \%$ \\
& $\mathrm{Rp}$ & 3.373 .393 .284 & & Biaya Modal & $\mathbf{1 2 \%}$ \\
\hline
\end{tabular}

Sumber: Data diolah, 2019

Berikut merupakan perhitungan penanganan persediaan untuk produk Semen Dynamix $40 \mathrm{~kg}$ dengan menggunakan metode EOQ:

$\mathrm{EOQ}=\sqrt{\frac{2 \mathrm{DS}}{\mathrm{H}}}$

- $\quad$ Jumlah permintaan tahunan (D) $=27.756 \mathrm{zak}$

- Biaya pemesanan $(\mathrm{S}) \quad=\mathrm{Rp} 185.285$

- Biaya penyimpanan $(\mathrm{H}) \quad=\mathrm{Rp} 56.585$

Maka nilai Economic Order Quantity (EOQ) adalah:

$\mathrm{EOQ}=\sqrt{\frac{2 \times 27.756 \times 185.285}{56.585}}$ 
$\mathrm{EOQ}=426 \mathrm{zak}$

Jadi, jumlah pesanan ekonomis dalam satu kali pemesanan produk Semen Dynamix $40 \mathrm{~kg}$ adalah 426 zak. Berdasarkan cara perhitungan tersebut, maka hasil perhitungan Economic Order Quantity (EOQ) pada persediaan produk klasifikasi A UD. Sinar Jaya adalah sebagai berikut:

Tabel 4.

Hasil Perhitungan Economic Order Quantity

\begin{tabular}{clccc} 
No & \multicolumn{1}{c}{ Nama Produk } & Satuan & EOQ & $\begin{array}{c}\text { Frekuensi } \\
\text { Pemesanan }\end{array}$ \\
& & & & \\
\hline 1 & Semen Dynamix 40 kg & zak & 426 & 65 \\
2 & Semen Tiga Roda 50 kg & zak & 147 & 85 \\
3 & Semen Merah Putih 40 kg & zak & 258 & 19 \\
4 & Semen Tiga Roda 40 kg & zak & 111 & 21 \\
5 & Trindek Soto Biru 6,20 m & lbr & 16 & 23 \\
6 & Seng Atap 0,20x180x11 (Gelombang Kecil) & lbr & 55 & 23 \\
7 & Asbes Atap Elephant 180x80 & lbr & 82 & 21 \\
8 & Trindek Soto Silver 6,20 m & lbr & 15 & 20 \\
9 & Kalsiboard Ling 240x120 & lbr & 46 & 25 \\
10 & Seng Atap 0,20x180x25 (Gelombang Besar) & lbr & 51 & 21 \\
\hline
\end{tabular}

Sumber: Data diolah, 2019

Dari hasil perhitungan EOQ di atas, dapat diketahui kuantitas tiap produk yang dibeli perusahaan setiap kali melakukan pemesanan dan berapa frekuensi pemesanan pada masing-masing unit produk dalam satu tahun. Dengan perhitungan tersebut, maka perusahaan akan memperoleh biaya yang ekonomis sehingga dapat meminimalkan biaya yang dikeluarkan akibat adanya persediaan. Berdasarkan hasil perhitungan EOQ pada tabel 3, diperoleh hasil bahwa jumlah pesanan tertinggi adalah 426 unit dengan frekuensi pemesanan sebanyak 65 kali pada produk Semen Dynamix $40 \mathrm{~kg}$, sedangkan jumlah pesanan terendah sebanyak 15 unit dengan frekuensi pemesanan 20 kali pada produk Trindex Soto Silver 6,20m.

Dari teori EOQ yang digunakan terdapat kelemahan yang membuat metode ini tidak dapat selalu diaplikasikan. Kelemahan tersebut yaitu dari cara menentukan permintaan per hari adalah konstan yang diperoleh dari permintaan tahunan setiap jenis produk dibagi dengan jumlah hari kerja UD. Sinar Jaya (340 hari). Sesuai dengan pengamatan, penjualan dari perusahaan berfluktuasi setiap bulannya. Sehingga kalau metode EOQ diterapkan dalam kondisi yang fluktuatif, penerapannya kurang tepat. Maka, diasumsikan bahwa metode EOQ dapat diterapkan apabila permintaan produk adalah relatif atau rata-rata hampir mendekati setiap harinya.

Safety stock merupakan persediaan yang berguna untuk mengantisipasi ketidakpastian permintaan terhadap suatu produk. Perhitungan safety stock dilakukan dengan mengalikan nilai service level atau tingkat layanan yang ditetapkan perusahaan dengan rata-rata permintaan per hari dan lead time dari 
produk UD. Sinar Jaya. Berdasarkan persamaan safety stock yang digunakan, lead time dalam hal ini bukanlah waktu menunggu mulai dari melakukan pemesanan hingga pesanan diterima, tetapi lead time yang dimaksud yakni rata-rata keterlambatan pengiriman dari pemasok yang dapat diakibatkan oleh cuaca yang tidak mendukung dan kondisi fisik dari kendaraan yang digunakan. Oleh karena itu, dapat diasumsikan bahwa rata-rata keterlambatan pengirimannya yaitu 2 hari. Selanjutnya, service level yang digunakan yakni sebesar 95 persen yang berarti perusahaan mampu melayani kebutuhan konsumen sebesar 95 persen dan hanya 5 persen tidak bisa memenuhi pelayanannya. Bersumber pada tabel distribusi normal, besar service level 95 persen adalah 1,65. Terakhir, dalam menentukan rata-rata permintaan per hari dliakukan dengan membagi permintaan tahunan setiap jenis produk dengan jumlah hari kerja UD. Sinar Jaya yang sudah ditentukan yakni 340 hari.

Tabel 5.

Hasil Perhitungan Safety Stock

\begin{tabular}{clcc}
\hline No & \multicolumn{1}{c}{ Nama Produk } & Satuan & SS \\
& & zak & 269 \\
\hline 1 & Semen Dynamix 40 kg & zak & 121 \\
2 & Semen Tiga Roda $50 \mathrm{~kg}$ & zak & 49 \\
3 & Semen Merah Putih 40 kg & zak & 22 \\
4 & Semen Tiga Roda 40 kg & lbr & 4 \\
5 & Trindek Soto Biru 6,20 m & lbr & 12 \\
6 & Seng Atap 0,20x180x11 (Gelombang Kecil) & lbr & 17 \\
7 & Asbes Atap Elephant 180x80 & lbr & 3 \\
8 & Trindek Soto Silver 6,20 m & lbr & 11 \\
9 & Kalsiboard Ling 240x120 & lbr & 10 \\
10 & Seng Atap 0,20x180x25 (Gelombang Besar) & & \\
\hline
\end{tabular}

Sumber: Data diolah, 2019

Dari hasil perhitungan safety stock di atas, dapat diketahui berapa unit produk yang perlu diadakan perusahaan untuk mengantisipasi ketidakpastian permintaan selama masa keterlambatan pengiriman. Hal tersebut dilakukan perusahaan agar dapat memastikan masih tersedianya stok persediaan di gudang, sehingga tidak akan terjadi stockout atau kekurangan persediaan. Berdasarkan perhitungan safety stock pada tabel 4 diperoleh hasil bahwa jumlah persediaan pengaman tertinggi adalah sebanyak 269 unit pada produk Semen Dynamix $40 \mathrm{~kg}$, sedangkan jumlah persediaan pengaman terendah adalah sebanyak 3 unit pada produk Trindex Soto Silver $6,20 \mathrm{~m}$.

Reorder point merupakan titik dimana perusahaan melakukan pemesanan kembali terhadap produk yang dimiliki agar aktivitas perusahaan dapat berjalan dengan lancar. Perhitungan reorder point dengan mengalikan terlebih dahulu ratarata permintaan per hari setiap jenis produk dengan lead time. Berdasarkan persamaan reorder point yang digunakan, dimana permintaan per hari setiap jenis 
produk dianggap konstan dan lead time yang merupakan waktu tunggu mulai dari melakukan pemesanan hingga pesanan diterima lamanya yakni 7 hari. Adapun hasil dari perhitungan reorder point masing-masing produk UD. Sinar Jaya yang masuk dalam klasifikasi A adalah sebagai berikut:

Tabel 6.

Hasil Perhitungan Reorder Point

\begin{tabular}{clcc}
\hline \multicolumn{1}{c}{ Nama Produk } & Satuan & ROP \\
& & & \\
\hline 1 & Semen Dynamix 40 kg & zak & 571 \\
2 & Semen Tiga Roda $50 \mathrm{~kg}$ & zak & 256 \\
3 & Semen Merah Putih 40 kg & zak & 103 \\
4 & Semen Tiga Roda 40 kg & zak & 47 \\
5 & Trindek Soto Biru 6,20 m & $\mathrm{lbr}$ & 8 \\
6 & Seng Atap 0,20x180x11 (Gelombang Kecil) & $\mathrm{lbr}$ & 26 \\
7 & Asbes Atap Elephant 180x80 & $\mathrm{lbr}$ & 35 \\
8 & Trindek Soto Silver 6,20 m & $\mathrm{lbr}$ & 6 \\
9 & Kalsiboard Ling 240x120 & $\mathrm{lbr}$ & 24 \\
10 & Seng Atap 0,20x180x25 (Gelombang Besar) & $\mathrm{lbr}$ & 22 \\
\hline
\end{tabular}

Sumber: Data diolah, 2019

Dari hasil perhitungan reorder point di atas, dapat diketahui di kuantitas berapa perusahaan melakukan pemesanan kembali. Hal tersebut dilakukan perusahaan untuk memastikan pemesanan produk berjalan dengan lancar sehingga tidak akan terjadi kekhawatiran akan menumpuknya produk di gudang ataupun khawatir akan menghadapi kekecewaan pelanggan karena kehabisan stok produk. Berdasarkan perhitungan reorder point pada tabel 4.5, diperoleh hasil bahwa titik pemesanan ulang tertinggi ada pada produk Semen Dynamix $40 \mathrm{~kg}$ yakni saat tersisa 571 zak, sedangkan titik terendah ada pada produk Trindex Soto Silver 6,20m yakni saat tersisa 6 lembar.

Bersumber pada teori reorder point yang digunakan, berasumsi bahwa permintaan selama lead time dan lead time itu sendiri adalah konstan. Ketika dihadapkan dengan kondisi yang berfluktuasi, penerapan teori tersebut dirasa kurang tepat. Maka dari itu, dalam kondisi yang fluktuatif perhitungan reorder point dapat digunakan dengan asumsi bahwa persediaan tambahan berupa safety stock atau persediaan pengaman haruslah ditambahkan. Di samping itu, dalam penentuan reorder point besaran persediaan pengaman dan persediaan maksimal sangat perlu diperhatikan karena ketiga hal tersebut memiliki hubungan yang saling berkaitan satu sama lain.

Persediaan maksimal merupakan jumlah persediaan yang paling banyak ada di gudang. Perhitungan persediaan maksimal dilakukan dengan menjumlahkan EOQ dengan safety stock pada produk UD. Sinar Jaya yang masuk dalam klasifikasi A. Adapun hasil dari perhitungan persediaan maksimal adalah sebagai berikut: 
Tabel 7.

Hasil Perhitungan Persediaan Maksimal

\begin{tabular}{clcc}
\hline No & \multicolumn{1}{c}{ Nama Produk } & Satuan & $\begin{array}{c}\text { Persediaan } \\
\text { Maksimal }\end{array}$ \\
\hline 1 & Semen Dynamix 40 kg & zak & 696 \\
2 & Semen Tiga Roda $50 \mathrm{~kg}$ & zak & 267 \\
3 & Semen Merah Putih 40 kg & zak & 306 \\
4 & Semen Tiga Roda 40 kg & zak & 133 \\
5 & Trindek Soto Biru 6,20 m & $\mathrm{lbr}$ & 20 \\
6 & Seng Atap 0,20x180x11 (Gelombang Kecil) & $\mathrm{lbr}$ & 68 \\
7 & Asbes Atap Elephant 180x80 & $\mathrm{lbr}$ & 99 \\
8 & Trindek Soto Silver 6,20 m & $\mathrm{lbr}$ & 18 \\
9 & Kalsiboard Ling 240x120 & $\mathrm{lbr}$ & 58 \\
10 & Seng Atap 0,20x180x25 (Gelombang Besar) & $\mathrm{lbr}$ & 61 \\
\hline
\end{tabular}

Sumber: Data diolah, 2019

Berdasarkan hasil perhitungan persediaan maksimal diperoleh hasil bahwa produk dengan jumlah persediaan maksimal paling tinggi ada pada Semen Dynamix $40 \mathrm{~kg}$ yakni sebanyak 696 zak, sedangkan produk dengan jumlah persediaan maksimal terendah ada pada Trindex Soto Silver 6,20m yakni sebanyak 18 lembar. Dari hasil perhitungan tersebut, perusahaan dapat menentukan berapa jumlah persediaan paling banyak yang boleh ada di gudang dengan tepat dan tidak berlebih sehingga dapat membuka kesempatan setiap jenis produk untuk menggunakan fasilitas gudang.

Dari hasil perhitungan persediaan maksimal di atas dan mengingat grafik hubungan dari safety stock, reorder point, dan persediaan maksimal itu sendiri, dapat diasumsikan bahwa permintaan bersifat konstan sepanjang waktu sehingga gambarnya akan menjadi seperti gigi gergaji. Oleh karena itu, perlu diingat bahwa besaran reorder point tidak boleh lebih tinggi dari besaran persediaan maksimal.

Inventory turnover merupakan perhitungan yang menyatakan tingkat kecepatan perputaran persediaan menjadi kas atau piutang dagang. Tingkat perputaran persediaan ini menunjukkan bagaimana jalannya operasional perusahaan dalam memesan produk serta mendistribusikannya kepada pelanggan. Perhitungan inventory turnover dilakukan dari penerapan persediaan yang dilakukan perusahaan, kemudian dibandingkan dengan inventory turnover metode EOQ untuk mengetahui metode yang mana menghasilkan tingkat perputaran yang lebih tinggi. Semakin tinggi tingkat perputaran persediaan, semakin sering produk terjual sehingga dapat menambah keuntungan perusahaan. Adapun perbandingan hasil dari perhitungan inventory turnover perusahaan dengan inventory turnover EOQ pada masing-masing produk UD. Sinar Jaya yang masuk dalam klasifikasi A adalah sebagai berikut: 
Tabel 8.

Hasil Perhitungan Inventory Turnover

\begin{tabular}{clccc}
\hline No & \multicolumn{1}{c}{ Nama Produk } & Satuan & $\begin{array}{c}\text { ITO } \\
\text { Perusahaan }\end{array}$ & ITO EOQ \\
\hline 1 & Semen Dynamix 40 kg & zak & 205 & 231 \\
2 & Semen Tiga Roda 50 kg & zak & 118 & 210 \\
3 & Semen Merah Putih 40 kg & zak & 52 & 222 \\
4 & Semen Tiga Roda 40 kg & zak & 32 & 122 \\
5 & Trindek Soto Biru 6,20 m & $\mathrm{lbr}$ & 27 & 101 \\
6 & Seng Atap 0,20x180x11 (Gelombang Kecil) & $\mathrm{lbr}$ & 57 & 216 \\
7 & Asbes Atap Elephant 180x80 & $\mathrm{lbr}$ & 127 & 107 \\
8 & Trindek Soto Silver 6,20 m & $\mathrm{lbr}$ & 79 & 100 \\
9 & Kalsiboard Ling 240x120 & $\mathrm{lbr}$ & 40 & 72 \\
10 & Seng Atap 0,20x180x25 (Gelombang Besar) & $\mathrm{lbr}$ & 20 & 90 \\
\hline Sumber: Data diolah, 2019
\end{tabular}

Sumber: Data diolah, 2019

Berdasarkan hasil perhitungan inventory turnover, dapat diketahui bahwa dengan menerapkan metode EOQ, hampir seluruh produk yang masuk dalam klasifikasi A kecuali produk Asbes Atap Elephant 180x80 menghasilkan tingkat perputaran yang lebih tinggi dibandingan inventory turnover yang diterapkan perusahaan. Dengan hasil tersebut mengindikasikan bahwa tingkat perputaran persediaan menggunakan metode EOQ mampu lebih cepat memutar persediaan menjadi kas sehingga dapat memaksimalkan keuntungan yang diperoleh perusahaan.

Total biaya persediaan merupakan keseluruhan biaya yang dikeluarkan perusahaan dalam menangani persediaan yang dimiliki. Komponen yang masuk dalam total biaya persediaan yaitu biaya pemesanan dan biaya penyimpanan yang dikeluarkan selama satu periode. Perhitungan dilakukan dari menghitung total biaya persediaan dengan metode yang diterapkan perusahaan (metode sesungguhnya), lalu dibandingkan dengan menghitung total biaya persediaan dengan metode EOQ (metode yang seharusnya). Besarnya perbandingan total biaya persediaan pada produk yang masuk dalam klasifikasi A adalah sebagai berikut:

Tabel 9.

Hasil Perhitungan Total Biaya Persediaan

\begin{tabular}{cccc}
\hline \multicolumn{2}{c}{ Metode Perusahaan } & \multicolumn{2}{c}{ Metode EOQ } \\
\hline Biaya Penyimpanan & Biaya Pemesanan & Biaya Penyimpanan & Biaya Pemesanan \\
\hline 19.236 .229 & 23.821 .908 & 12.438 .743 & 20.277 .774 \\
43.058 .137 & & \multicolumn{2}{c}{32.716 .517} \\
\hline SUmber:
\end{tabular}

Sumber: Data diolah, 2019 
Dari hasil perhitungan dapat dilihat bahwa total biaya persediaan yang dikeluarkan dari metode yang diterapkan perusahaan saat ini lebih tinggi dibandingkan total biaya dengan penerapan metode EOQ atau yang seharusnya. Metode dari perusahaan mengeluarkan biaya persediaan sebanyak Rp 43.058.137, sedangkan dengan metode EOQ hanya mengeluarkan biaya persediaan sebanyak Rp 32.716.517. Hal ini menunjukkan bahwa dengan menerapkan metode EOQ, seharusnya perusahaan dapat menghemat pengeluaran biaya persediaan sebanyak Rp $10.341 .620(24,02 \%)$ jika dibandingkan dengan metode perusahaan yang sesungguhnya.

Perhitungan tersebut diperoleh berdasarkan asumsi bahwa $\mathrm{D}$ atau permintaan setiap jenis produk klasifikasi A yang digunakan baik dalam metode perusahaan maupun metode EOQ adalah sama, yakni permintaan atau produk yang betul-betul terjual. Oleh karena itu, perusahaan dapat mengetahui berapa sebenarnya produk yang dibutuhkan pada tahun 2019, sehingga atas dasar itu dapat diturunkan berapa kuantitas produk yang seharusnya dipesan setiap kali melakukan pemesanan agar jumlah yang dijual tercapai. Padahal perusahaan selama ini memesan jauh lebih banyak daripada yang dijual sehingga persediaan setiap jenis produk menjadi tinggi. Hal tersebut mengakibatkan akhirnya biaya persediaan dari metode EOQ jauh lebih rendah daripada yang sesungguhnya dilakukan oleh perusahaan. Berdasarkan kondisi tersebut, untuk tahun berikutnya perusahaan harus bisa melakukan estimasi berapa sebenarnya kebutuhan setiap jenis produk yang masuk dalam klasifikasi A, sehingga perusahaan bisa lebih efisien dalam mengukur kinerja persediaan dengan membeli produk sebanyak EOQ yang disesuaikan dengan kebutuhan.

Berdasarkan hasil analisis ABC yang dilakukan pada persediaan produk dari UD. Sinar Jaya tahun 2019, perusahaan dapat mengetahui kelompok produk yang dikategorikan sangat kritis, medium, dan kurang kritis. Kelompok-kelompok tersebut diklasifikasikan menjadi 3 kategori, yakni klasifikasi A, klasifikasi B, dan klasifikasi $\mathrm{C}$ sesuai dengan tingkat kerusakan produk yang dimiliki. Berdasarkan hasil perhitungan Economic Order Quantity (EOQ) pada produk UD. Sinar Jaya yang masuk dalam klasifikasi A, perusahaan dapat mengetahui berapa kuantitas pesanan ekonomis setiap kali melakukan pemesanan dan berapa frekuensi pemesanan yang seharusnya dilakukan perusahaan dalam satu periode.

Berdasarkan hasil perhitungan safety stock produk klasifikasi A pada UD. Sinar Jaya, perusahaan dapat mengetahui berapa banyak persediaan pengaman yang perlu disediakan di gudang untuk mengantisipasi ketidakpastian permintaan dari pelanggan. Berdasarkan hasil perhitungan reorder point pada produk UD. Sinar Jaya yang masuk dalam klasifikasi A, perusahaan dapat mengetahui pada tingkat persediaan berapa harus melakukan pemesanan kembali untuk memastikan pemesanan produk berjalan dengan lancar.

Berdasarkan hasil perhitungan persediaan maksimal pada produk UD. Sinar Jaya yang masuk dalam klasifikasi A, perusahaan dapat mengetahui berapa jumlah persediaan paling banyak yang boleh ada di gudang sehingga tidak terjadi penumpukan produk yang dimiliki perusahaan. Berdasarkan hasil perhitungan inventory turnover (ITO) yang dilakukan dengan membandingkan ITO dari metode 
yang diterapkan perusahaan dengan ITO dari metode EOQ atau yang seharusnya, perusahaan dapat mengetahui bahwa penerapan metode EOQ mampu lebih cepat memutar persediaan menjadi kas atau piutang dagang. Berdasarkan hasil perbandingan total biaya persediaan antara metode yang sesungguhnya diterapkan perusahaan dengan penerapan metode EOQ atau yang seharusnya, dapat diketahui bahwa dengan metode EOQ perusahaan dapat menghasilkan efisensi total biaya persediaan yang dikeluarkan selama satu tahun.

\section{SIMPULAN}

Berdasarkan pembahasan hasil penelitian yang telah dilakukan, dapat disimpulkan bahwa persediaan merupakan salah satu aset termahal perusahaan yang berperan penting dalam kegiatan operasional perusahaan untuk menentukan keseimbangan antara investasi persediaan dan pelayanan pelanggan. Kinerja manajemen persediaan produk yang diterapkan UD. Sinar Jaya masih belum efisien karena perusahaan belum menerapkan sistem manajemen persediaan yang seharusnya, diantaranya mengklasifikasikan produk dengan analisis $\mathrm{ABC}$, lalu menentukan EOQ, menentukan safety stock, dan menentukan reorder point pada masing-masing unit klasifikasi A. Berdasarkan analisis $\mathrm{ABC}$, yang termasuk klasifikasi A (sangat kritis) sebanyak 10 produk (3,64\%) dengan nilai investasi $80,02 \%$, klasifikasi B (medium) sebanyak 63 produk $(22,91 \%)$ dengan nilai investasi 14,98\%, dan klasifikasi C (kurang kritis) sebanyak 202 produk $(73,45 \%)$ dengan nilai investasi $5 \%$.

Berdasarkan analisis EOQ, kuantitas pesanan ekonomis untuk produk klasifikasi A bervariasi mulai dari 15 hingga 426 unit dengan frekuensi pemesanan dari 19 hingga 85 kali. Berdasarkan analisis SS, ROP, dan persediaan maksimal untuk produk klasifikasi A, jumlah persediaan pengaman bervariasi mulai dari 3 hingga 269 unit, titik pemesanan kembali bervariasi mulai dari 6 hingga 571 unit, dan jumlah persediaan maksimal bervariasi mulai dari 18 hingga 696 unit. Berdasarkan analisis inventory turnover (ITO) memperoleh hasil bahwa dengan menerapkan metode EOQ, hampir seluruh produk klasifikasi A menghasilkan tingkat perputaran lebih tinggi dibandingkan ITO yang diterapkan sesungguhnya oleh perusahaan.

Kinerja manajemen persediaan produk yang belum efisien akhirnya dibuktikan dengan total biaya persediaan yang dikeluarkan dari metode perusahaan atau yang sesungguhnya pada tahun 2019 sebesar Rp 43.058.137, sedangkan dengan metode EOQ, seharusnya total biaya persediaan yang dikeluarkan sebesar Rp 32.716.517. Hal ini menunjukkan bahwa dengan menerapkan metode EOQ, perusahaan dapat menghemat pengeluaran biaya persediaan sebanyak $\mathrm{Rp}$ 10.341.620 atau sebesar 24,02\%.

UD. Sinar Jaya sebaiknya melakukan peninjauan kembali terhadap metode yang dilakukan maupun kebijakan yang diterapkan perusahaan dalam menangani persediaan produk yang dimiliki. UD. Sinar Jaya diharapkan mempertimbangkan penerapan pengendalian persediaan mulai dari analisis ABC yang mengklasifikasikan produk menjadi 3 kategori, yaitu sangat kritis, medium, dan kurang kritis untuk mempermudah perusahaan dalam melakukan penanganan 
persediaan. Setelah itu, menggunakan metode EOQ yang melakukan pemesanan dengan kuantitas ekonomis, mengadakan persediaan pengaman, dan juga mempertimbangkan titik pemesanan kembali. Dengan pertimbangan tersebut, perusahaan akan mampu mengefisiensikan biaya persediaan sehingga dapat memaksimalkan keuntungan dan meningkatkan kinerja manajemen persediaan produk yang dimiliki.

UD. Sinar Jaya perlu mempersiapkan karyawan atau SDM yang mampu mengaplikasikan ataupun mengoperasikan software Microsoft Excel atau aplikasi perangkat lunak sejenisnya untuk mempermudah pengelolaan data baik itu berupa jenis-jenis produk maupun melakukan perhitungan persediaan kedepannya. Penggunaan aplikasi tersebut akan sangat membantu perusahaan dalam menjaga ketersediaan data agar tidak hilang sehingga proses penyelesaian pekerjaan menjadi efektif dan efisien.

Untuk penelitian selanjutnya bisa menggunakan metode yang sama pada perusahaan yang berbeda untuk menentukan apakah metode EOQ benar-benar mampu mengefisiensikan biaya persediaan perusahaan dan memperhatikan kondisi-kondisi tertentu dalam pengaplikasian sistem manajemen persediaan menggunakan metode EOQ terutama pada kondisi yang tidak menentu atau berfluktuasi agar penggunaannya menjadi tepat sasaran.

\section{REFERENSI}

Abdul, F. W. (2018). Lean Manufacturing Implementation in Inventory Control as a Repair Process. Jurnal Logistik Indonesia, 2(1), 31-36.

Alfatih, M. R. (2017). Pengendalian Persediaan Barang Dagangan pada Grosir dan Swalayan Surya di Desa Kwadungan dengan Metode Analisis ABC. Artikel Skripsi Universitas Nusantara PGRI Kediri, 1(1), 1-16.

Andira, O. E. (2016). Analisis Persediaan Bahan Baku Tepung Terigu Menggunakan Metode EOQ (Economic Order Quantity) pada Roti Puncak Makassar. Jurnal Ekonomi Bisnis, 21(3), 201-208.

Asri, Y., Siregar, R. R., \& Sihombing, H. (2018). Resource Inventory Management System Laboratory Terintegrasi Web. Jurnal Ilmu Teknik Dan Komputer, 2(1), $55-63$.

Barwa, T. M. (2015). Inventory Control as An Effective Decision-Making Model and Implementations for Company's Growth. International Journal of Economics, Finance and Management Sciences, 3(5), 465-472.

Beck, F. G., Grosse, E. H., \& Teßmann, R. (2015). An Extension for Dynamic LotSizing Heuristics. Production \& Manufacturing Research, 3(1), 20-35.

Brahmandhika, I. B. M., Dewi, R. K., \& Suamba, I. K. (2016). Analisis Pengendalian Persediaan Bahan Baku Tauco di Perusahaan Kecap Manalagi 
Kota Denpasar Provinsi Bali. E-Jurnal Agribisnis Dan Agrowisata, 5(3), 618628.

Chebet, E. (2019). Effects of Inventory Management System on Firm Performance - An Empirical Study. International Journal of Innovative Science and Research Technology, 4(9), 91-100.

Gordon, S. A., \& Gupte, J. (2016). Overview of the Classic Economic Order Quantity Approach to Inventory Management. The Business Age, 1(1), 24552470 .

Hafnika, F., Farmaciawaty, D. A., Adhiutama, A., \& Basri, M. H. (2016). Improvement of Inventory Control Using Continuous Review Policy in A Local Hospital at Bandung City, Indonesia. The Asian Journal of Technology Management (AJTM), 9(2), 109-119. https://doi.org/10.12695/ajtm.2016.9.2.5

Handoko, T. H. (2019). Dasar-Dasar Manajemen Produksi dan Operasi (1st ed.). Yogyakarta: BPFE.

Heizer, J., \& Render, B. (2015). Manajemen Operasi (Manajemen Keberlangsunan dan Rantai Pasokan) (11th ed.). Jakarta: Salemba Empat.

Juventia, J., \& Hartanti, L. P. . (2016). Analisis Persediaan Bahan Baku PT. BS dengan Metode Economic Order Quantity (EOQ). Jurnal Gema Aktualita, 5(1), 55-63.

Kumar, G. A., Anzil, K. A., Ashik, K., James, A. T., \& Ashok, J. K. (2017). Effective Inventory Management System through Selective Inventory Control. Imperial Journal of Interdisciplinary Research, 3(6), 152-156.

Lestari, R. I. (2015). Designing Inventory Management System: A Case of Retail Store in Cianjur, Indonesia. Management Finance Economics, 1(1), 275-282.

Listyorini, P. I. (2016). Perencanaan dan Pengendalian Obat Generik dengan Metode Analisis ABC, EOQ dan ROP (Studi Kasus di Unit Gudang Farmasi RS PKU 'Aisyiyah Boyolali). Jurnal Ilmiah Rekam Medis Dan Informatika Kesehatan, 6(2), 19-25.

Macias, R. G. (2020). Inventory Management and Logistics Optimization: A Data Mining Practical Approach. Scientific Journal of Logistics, 16(4), 535-547.

Maryati, S. (2016). Evaluating the Performance of Inventory Management The Production Division of PT. Tiga Serangkai Surakarta as a Case Study. Shirkah: Journal of Economics and Business, 1(1), 93-112. 
Micah, E. E. M., Adekunle, M. K., \& Adeboye, A. (2019). Assesment of Electronic Inventory Management Systems and Utilisation in the Healthcare System in Abuja, FCT Nigeria. Europan Journal of Business and Inovation Research, $7(6), 1-17$.

Mujiono, L. P. R., \& Fauji, D. A. S. (2017). Analisis Pengendalian Persediaan Pipa Air PVC Menggunakan Metode ABC pada Toko Bangunan UD. Mansur Kecamatan Papar. Simki-Economic, 1(3), 2-11.

Najoan, R. J., Palandeng, I. D., \& Sumarauw, J. S. . (2019). Analisis Pengendalian Persediaan Semen dengan Menggunakan Metode EOQ pada Toko Sulindo Bangunan. Jurnal EMBA, 7(3), 4387-4396.

Nilawati, A., \& Giyanti, I. (2016). Integrasi Metode ABC dan Multi Item EOQ with Discount dalam Pengendalian Persediaan Obat Dispensing (Studi Kasus: Apotek XYZ). Jurnal Ilmiah Teknik Industri Dan Informasi, 4(2), 82-88.

Nugraha, A., Sukardi, \& Rifin, A. (2016). Efficiency of Raw Material Inventories in Improving Supply Chain Performance of CV. Fiva Food. Indonesian Journal of Business and Entrepreneurship, 2(1), 23-32.

Pujawan, I. N., \& Mahendrawati. (2010). Supply Chain Management (2nd ed.). Surabaya: Guna Widya.

Putra, D. G. E. N., \& Purnawati, N. K. (2018). Kinerja Manajemen Persediaan Barang Dagangan PT. Artha Dinamis Sentosa Bali. E-Jurnal Manajemen, 7(10), 5599-5627.

Putra, I. M. A. D., \& Rahyuda, A. G. (2019). Analisis Kinerja Manajemen Persediaan di Barjaz Company Menggunakan Pendekatan EOQ. E-Jurnal Manajemen, 8(1), 7163-7190.

Radasanu, A. C. (2016). Inventory Management, Service Level and Safety Stock. Journal of Public Administration, Finance and Law, 9(1), 145-153.

Rambitan, B. F., Sumarauw, J. S. B., \& Jan, A. H. (2018). Analisis Penerapan Manajemen Persediaan pada CV. Indospice Manado. Jurnal EMBA, 6(3), $1448-1457$.

Shu, X. H., \& Indriyani, R. (2015). Analisis Inventory Management pada PT. Sarana Lubritama Semesta. Jurnal AGORA, 3(1), 470-476.

Soni, H., Pitroda, J., \& Bhavshar, J. J. (2016). Analyzing Inventory Material Management Control Technique on Residential Construction Project. International Journal of Advanced Research in Engineering, Science and Management, 2(3), 3071-3077. 
Sunhal, A. S., \& Mangal, D. (2017). Analysis of Inventory Management in a Supply Chain by Using Economic Order Quantity (EOQ) Model. International Journal of Engineering Sciences and Research Technology, 6(10), 303-309.

Supit, T., \& Jan, A. H. (2015). Analisis Persediaan Bahan Baku pada Industri Mebel di Desa Leilem. Jurnal EMBA, 3(1), 1230-1241.

Syafitri, L. (2015). Pengaruh Inventory Turnover dan Total Asset Turnover terhadap Profitabilitas pada CV. Teluk Kenanga Ogan Ilir. Jurnal Ilmiah STIE MDP, 4(2), 74-83.

Yanti, T. H., \& Farida, Y. (2016). Analisis ABC dalam Perencanaan Obat Antibiotik di Rumah Sakit Ortopedi di Surakarta. Journal of Pharmaceutical Science and Clinical Research, 1(1), 51-57. 